\title{
INNOVATION IN COUNTERACTING INSURANCE FRAUD
}

\author{
ANNA BERA \\ University of Szczecin, Faculty of Management and Economics of Services, POLAND \\ e-mail: anna.bera@wzieu.pl

\begin{tabular}{l|l} 
RECEIVED & 6 November 2018 \\
ACCEPTED & 3 December 2018 \\
JEL & \\
CLASSIFICATION & M20, M21, M29
\end{tabular} \\ KEYWORDS insurance, insurance fraud, instruments for countering \\ ABSTRACT The subject of this article are insurance crime and instruments to counteract them. Insurance fraud covers \\ both criminal offenses and economic crimes, whose common feature is that they infringe the interests of the \\ insurance sector, regardless of their source. Only in the U.S. and UK alone, the losses resulting from insurance \\ frauds are run in billions. Insurance fraud is a complex phenomenon with complicated phenomenology and \\ etiology. The study focuses on innovative instruments for counteracting insurance fraud. The research pro- \\ cess required the application of the following research methods and techniques: literary critical analysis, desk \\ research method, observation, qualitative methods, and techniques of graphic presentation of the research \\ results.
}

\section{Introduction}

Insurance fraud is a serious and growing social and financial problem, as it breaches both the law and the interests of insured persons. If effective, these actions become the source of insurers' losses. A characteristic feature of insurance fraud is also the multitude of criminal methods occurring on the insurance market and a wide range of entities involved in this procedure. 
It seems that traditional methods of combating frauds are inadequate. Research on insurance frauds usually focuses on determining the characteristics of fraudulent claims, which in turn draws attention to the current wave of forensic technology and data mining employed in order to detect them. An alternative approach is to understand and then optimize existing fraud detection practices.

The following research methods and techniques were used when preparing this article: literary critical analysis, desk research method, observation, qualitative methods, and techniques of graphic presentation of the research results. The critical analysis of literature was aimed at assessing the state of knowledge regarding the phenomenon of insurance fraud. In the phase of gathering the actual knowledge, the desk research method was used. When examining the financial reports of insurance institutions, the scale of the insurance fraud was identified, whereas in the empirical part, solutions applied to counteract insurance fraud were classified. On this basis, conclusions and recommendations were formulated.

\section{The conceptual range and positioning of insurance fraud by insurers}

Attempts to explain the phenomenon of insurance fraud are undertaken not only on the economic, but also legal and social level. By definition, insurance fraud is established by agreement of the parties and can be described as (Smith, Roberson, 1971, p 1166): "...a contract whereby an insurer promises to pay the insuree a sum of money or some other benefit upon the happening of a contingency or fortuitous event, which is beyond the control of the contracting parties and in which the promise is non-contractual."

There are many ways to commit insurance frauds. Gill, Woolley and Gill (1994, p. 74) define fraud as intentionally submitting a fictitious or inflated claim, adding additional elements to a claim and being dishonest in any way with the intention of obtaining more than a justified compensation.

When judging the perpetrators in the Polish legal system, the provisions of Articles 286 and 298 of the Penal Code (p.c.) are applicable. Under Article 286 p.c., prohibited acts were classified as:

a) extortion scam - perpetrator's action aiming at misleading the insurer or taking advantage of their error concerning the circumstances affecting their liability under the insurance contract, taken in order to obtain a financial gain if the payment was made;

b) attempted extortion scam - action presented in Article 13 p.c. and Article 286 p.c., i.e. perpetrator's action aiming at misleading the insurer or taking advantage of their error concerning the circumstances affecting their liability under the insurance contract, taken in order to obtain a financial gain if the payment was not made;

In the case of Article 298 p.c., the responsibility of the perpetrator is as follows: Article 1. Whoever, in order to obtain compensation under an insurance contract, causes an event which provides grounds for a compensation payment shall be subject to the penalty of deprivation of liberty for 3 months to 5 years.

Article 2. Whoever had voluntarily prevented the payment of compensation, prior to instituting criminal proceedings, shall not be liable to punishment.

At present, insurance fraud can be divided into three groups (Zalewski, 2016, p. 43):

1. Client frauds (insured), for example, obtaining payment of undue compensations by deception. The simplicity of these cases is often demonstrated by the speed of the proceedings. 
2. Frauds committed among insurance companies by representatives of brokerage and insurance companies (natural persons), e.g. actions taken to the detriment of the company, assistance in fraud, corruption.

3. Corporate crime, i.e. criminality of collective entities (legal entities), for example, bid rigging, price fixing. At the same time, the following conclusions can be drawn from the surveys carried out by Insurance Europe Fraud in 2016:

- $54 \%$ of insurers believe that insurance fraud is the biggest threat to the insurance industry today,

- $64 \%$ of insurers indicated insurance fraud as one of a number of priorities in their organizations,

- $50 \%$ of insurers believe that data quality is a challenge for the organization, which is needed to respond effectively to fraud,

- Theft of data poses the greatest risk for insurers in the field of insurance fraud.

The phenomenon of insurance fraud, like all other phenomena forming part of the so-called "grey zone", is not measurable in a direct way. Not every perpetrator who attempted to obtain compensation for damages is detected and brought before the judicial authorities. As a result, the actual losses of insurers may repeatedly exceed the value of the disclosed insurance fraud. Furthermore, the various statistics constitute only an estimate of suspicion regarding insurance frauds, which employees of insurance companies disclosed on the basis of their knowledge, experience and evidence collected.

According to the report prepared by the Ministry of the Interior and the Ministry of Finance, the dominant mechanisms of crimes on the insurance market are (Ministry of the Interior, p. 16):

- false reporting of road collisions, for the purpose of obtaining indemnities or compensations by deception,

- false reporting of car theft, including those owned by banks and leasing companies (e.g. in the event of a threat to a loan repayment due to the borrower's worse financial situation),

- attempting at and obtaining compensations for deliberately caused fires by deception,

- obtaining claims under concluded accident insurance or life insurance contracts by deception, based on pre-arranged or arranged events covered by the insurance (intentional personal injury, false death certificates),

- collecting compensation from several insurance companies for the same damage,

- over-declaring the cost of repairs by using documents from maintenance facilities that are false of certify untruth,

- overvaluing insured objects (real estate, cars and other movable property) and certifying untruth by agents to enable obtaining a loan and greater compensation,

- obtaining guarantee of commercial debt payment by deception.

The international and domestic data, published, among others, by the Polish Chamber of Insurance (PIU), shows an increase in this type of crime. The Estimates of the European Insurance Committee (CEA) indicate that the value of fraud can account for $3 \%$ of premiums collected by insurance companies (Miksiewicz, p. 46). According to data obtained by PIU, the average annual loss from insurance fraud in 2011-2016 was in Section I - PLN 9,731,678, whereas in Section II - PLN 142,440,649. The median in the analyzed period was as follows: Section I - PLN 10,227 982, Section II - PLN 135,730,128. The annual values of losses of insurance companies are presented in Figure 1. 


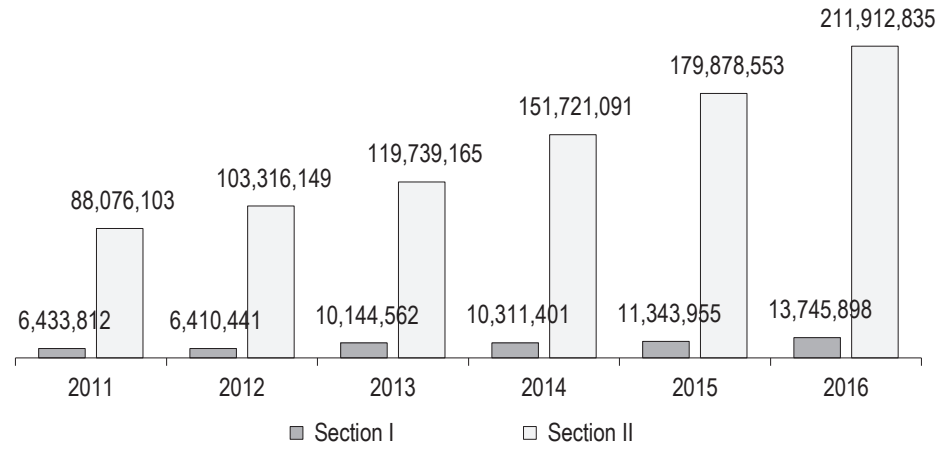

Figure 1. Value of extortions in Department I and II 1 in 2011-2016 (PLN)

Source: own work based on Majewski (2017), pp. 4-9.

The difference in the value of detected extortions between Sections I and II is partly due to the fact that the products of Section I are not equally subject to extortion. Classic life products, accident insurance, as well as group and sickness insurance can be used to generate undue claims. On the other hand, the group of products less subject to extortion include investment insurance, which, due to their structure, prevent obtaining compensation by false pretences (PIU, 2017, p. 9).

In addition to obtaining indemnities or compensations by false pretences, insurance companies also record insurance fraud outside the area of payment of compensations (Figure 2). In this case, the risk of crime concerns not the client, but mainly the insurance company. Dishonest employees and insurance intermediaries can be a serious source of financial loss.

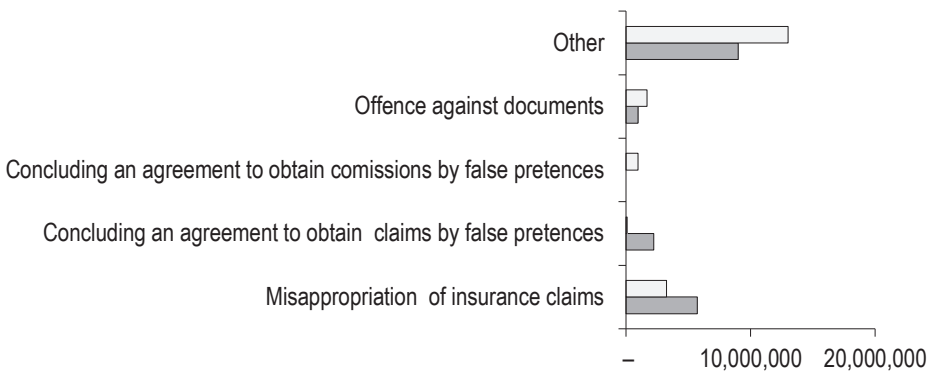

$\square$ Section I $\quad \square$ Section II

Figurle 2. Insurance fraud outside the payment area of compensations in Section I and II in 2016 (PLN)

Source: own work based on Majewski (2017), pp. 13, 29.

${ }^{1}$ In accordance with the Act on the insurance and reinsurance activities of 11 September 2015, insurance is divided into sections: Section I - Life Insurance, Section II - Other personal insurance and property insurance. 
In the "other" category, insurance companies indicate, in particular, money laundering, cybercrime and social engineering. Criminals tend to impersonate the person entitled to receive payments on claims and take over the payment by changing the bank account number.

\section{Instrumentarium for counteracting insurance fraud}

The constant emergence of new forms of fraudulent insurance claims on the market indicates that in order to combat insurance fraud, particular emphasis should be put on the development of innovative tools to counteract this phenomenon. To this end, IT tools used in insurance companies should be systematically developed in order to identify undesirable phenomena. The new tools are to help effectively identify fraud patterns of behaviour and anomalies, as well as indicate risks and threats. It appears that a large amount of data available in insurance companies can be properly analysed only when using dedicated IT systems, which, thanks to advanced analytics, are able to properly combine and interpret it (Dudek, 2017, p. 93). At the same time, another important element used in this process are networks of connections. The analysis of links between entities allows discovering hidden relationships and suspicious interdependencies between clients, accounts, vehicles, damage or other entities.

Thus, two main approaches applied to combat fraud by technology can be identified (Morley, Ball, Ormerod, 2016, p. 3). The first and perhaps most common is the use of data mining methods, in which systems make it possible to access databases of information on customers and claims, and cross-check it with external data sources for identification.

The other technology-based approach to combat fraud employs methods that aim at 'profiling' probable fraudsters, including techniques such as voice stress analysis. However, techniques such as voice stress analysis require direct contact of the insurance company with the insuree. This is somewhat difficult, as more and more insurance products are sold through external entities, e.g. insurance intermediaries and via the Internet.

According to a survey conducted by Accenture, a global company providing services in the field of new technologies and outsourcing, the most important initiatives taken by insurers to increase the detection of frauds include use of modelling techniques, improvement of data collection processes from both internal systems and external sources, increased support by the IT department. The research results indicate that in the next years insurers will focus mainly on organizational restructuring, training courses and process improvement in order to increase the level of fraud detection. The use of analytical methods (76\%), providing better IT support and optimization of data collection processes are becoming a priority (Figure 3 ).

Another important element is the development of analytical tools to identify damages resulting from frauds by assessing transactions in real time. This involves combating insurance fraud at the time of taking out insurance (and not, as before, only at the stage of claim settlement). 


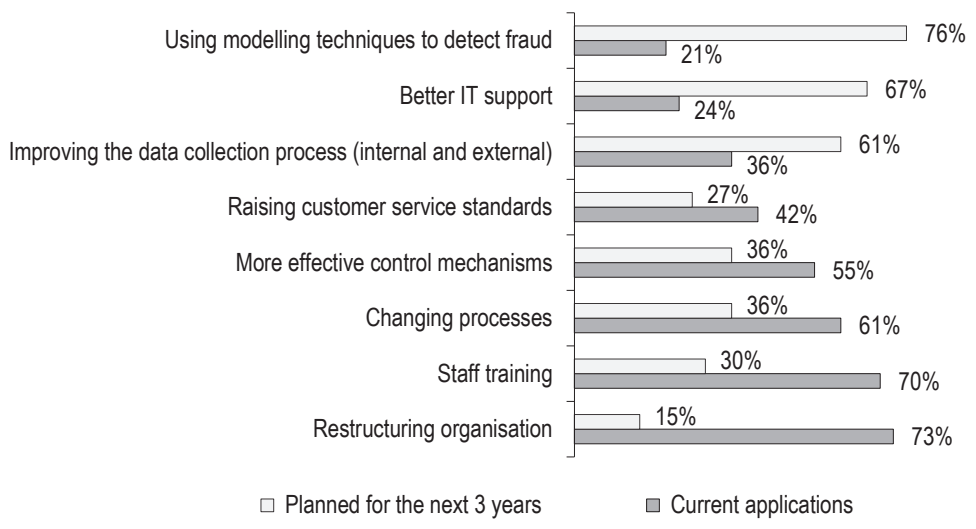

Figure 3. Key initiatives implemented by insurance companies to improve fraud detection

Source: Jak efektywnie... (2014), p. 4.

Insurance companies are beginning to implement new initiatives related to improving the detection of fraud in the area of damage, including, for example, the development of IT tools, improvement of data collection as well as development of modelling techniques and analytics to detect fraud. The movement towards the development of ICT solutions used in counteracting insurance fraud is associated with the following activities, i.e.:

1. Legislative measures. Activities aiming at creating a legal infrastructure giving rise to legislative actions in counteracting insurance fraud.

2. Procedural and administrative measures. Activities aiming at optimizing the use of the existing cyberspace infrastructure by introducing the best practices and standards in this field into the insurance practice. At this stage, both legal tools and mechanisms of "soft" regulations developed (created) by individual institutions of the insurance market can be used.

3. Preventive-educational measures. Activities regarding introduction of educational tools to the insurance practice (for example, through the organization of e-learning courses, educational spots, etc.). These activities should be carried out among current and future users of cyberspace, with their goal being strengthening the effect of the two previous activities and consolidating them among users. It is important to take these actions among the whole society, as knowledge about how to counteract and combat threats is a key element in the fight against them.

4. Technical measures. The key stage of activities that, based on procedural and organizational measures, introduces specific (developed) technical solutions (e.g. a platform to counteract and combat insurance fraud), which aim at reducing the risk of cyber threats. These activities are therefore carried out to expand the early warning system, as well as implement and maintain systemic preventive solutions.

The implementation of the above-mentioned measures is associated with cooperation on various levels, which should include:

- national cooperation between insurance market players, as well as the Police, ABW (Internal Security Agency), the Public Prosecutor's Office, etc., 
- cooperation with producers of devices and ICT systems (hardware and software), and other entities responsible for ICT security,

- cooperation with ICT entrepreneurs, the Office of Electronic Communications and users of cyberspace,

- international cooperation both in the area of the European Union and NATO.

Insurance companies face an urgent need to solve problems regarding obsolete systems and resigning from ineffective processes that make it difficult to detect frauds.

Obviously, it is almost impossible to completely eliminate the phenomenon of insurance fraud. However, it is possible to limit it to the extent that it does not affect the financial stability of insurers. To this end, insurance companies should pay particular attention to the above activities.

\section{Conclusions}

The development of innovative anti-fraud systems is the only possible way to increase effectiveness of detecting insurance frauds. The applied ICT solutions are a good chance to increase the transparency of business, as they allow for early detection of fraud, increasing the efficiency of preliminary investigations, greater involvement of operational units in counteracting fraud, and limiting expenses on counteracting crime. Nevertheless, it is also necessary to take into consideration the fact that the human factor remains the key element in detecting crime. Even if the system correctly identifies irregularities, the employee of the insurance company must analyse and address them appropriately, as well as make a decision regarding the next step. Thus, the conclusion is that insurance companies should be leaders in building and implementing modern solutions in detecting fraud and improving defense mechanisms in the area of technology, process and human resources.

\section{References}

Dudek, K. (2017). Dlaczego musimy stosować nowoczesne technologie w przeciwdziałaniu przestępczości ubezpieczeniowej? In: Przestępczość ubezpieczeniowa. Materiały Konferencyjne, t. 20, Szczecin: Szczecin-Expo.

Gill, K.M., Woolley, A., Gill, M. (2005). Insurance fraud: the business as a victim? In: M.Gill (ed.), Crime At Work (pp. 73-82). London: Palgrave Macmillan.

Jak efektywnie zwalczać przestępczość ubezpieczeniową? (2014). Raport merytoryczny. Warszawa: Accenture.

Majewski, P. (2017). Analiza danych dotyczących przestępstw ujawnionych w 2016 roku w związku z działalnością zakładów ubezpieczeń - członków Polskiej Izby Ubezpieczeń. Warszawa: Polska Izba Ubezpieczeń.

Miksiewicz, D. (2015). Charakterystyka przestępczości ubezpieczeniowej w Polsce. Studenckie Zeszyty Naukowe, 18 (27), $42-58$.

Program przeciwdziałania i zwalczania przestępczości gospodarczej na lata 2015-2020 (2015). Warszawa: Ministerstwo Spraw Wewnętrznych, Ministerstwo Finansów.

Smith, L.Y. Roberson, G.G. (1971). Business Law - Uniform Commercial Code. St. Paul, MN: West Publishing Co.

This survey was created in the run up to Insurance Fraud Europe - a networking summit taking place (2016). London: Insurance Fraud Europe.

Ustawa o działalności ubezpieczeniowej i reasekuracyjnej z dnia 11 września 2015. Dz.U. 2015, poz. 1844.

Ustawa z dnia 19 kwietnia 1969 r. Kodeks Karny. Dz.U., nr 13, poz. 94.

Zalewski, W. (ed.) (2016). Przestępczość ubezpieczeniowa: Etiologia, fenomenologia, przeciwdziałanie. Sopot: Wydawnictwo Arche.

Cite this article aS: Bera, A. (2018). Innovation in counteracting insurance fraud. European Journal of Service Management, 4 (28/1), 15-21. DOI: 10.18276/ejsm.2018.28/1-02. 